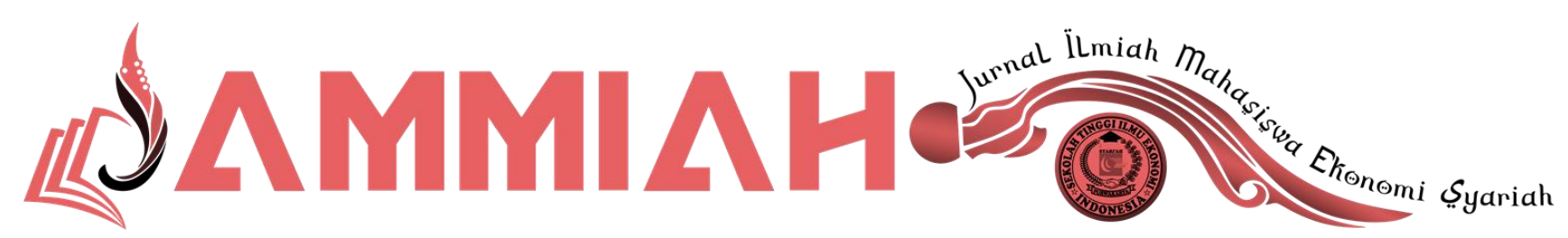

Volume 1 Nomor 2, September 2021

\title{
Prosedur Pembiayaan Paket Masa Depan (PMD) Di BTPN Syariah MMS Rengasdengklok, Karawang
}

\author{
Ajeng Rezkita Suci', Dewi Nurapiah², Yulia Purnama ${ }^{3}$ \\ 1,2,3 Sekolah Tinggi Ilmu Ekonomi Syariah (STIES) Indonesia Purwakarta \\ ${ }^{1}$ rezkita26@gmail.com \\ ${ }^{2}$ dewinurapiah@gmail.com \\ 3yuliauipurnama@gmail.com
}

\begin{abstract}
ABSTRAK
Bank syariah merupakan lembaga keuangan yang berfungsi sebagai penghimpun dana, penyalur dana dan menyediakan jasa-jasa perbankan kepada masyarakat yang mana sistem operasionalnya sesuai dengan syariat Islam. Fungsi penyaluran dana pada masyarakat dalam bank yaitu dengan adanya pembiayaan. BTPN Syariah merupakan salah satu lembaga keuangan yang menyelenggarakan fungsi pembiayaan melalui produk Pembiayaan Paket Masa Depan, (PMD). Tujuan penelitian ini untuk mengetahui Prosedur Pembiayaan Paket Masa Depan (PMD) Di BTPN Syariah MMS Rengasdengklok, Karawang. Hasil penelitian ini menyimpulkan bahwa paket Masa Depan adalah program terpadu BTPN Syariah yang diberikan kepada sekelompok perempuan di pedesaan yang ingin berusaha dan memiliki impian untuk merubah hidup, tetapi tidak memiliki akses ke layanan perbankan. PMD mengedepankan 4 (empat) prilaku efektif dalam menggapai mimpi mereka yaitu BDKS (Berani berusaha, Disiplin, Kerja Keras dan Saling Bantu). Syarat-syarat untuk menjadi nasabah PMD di bank BTPN Syariah, sebagai berikut: 1. Warga Negara Indonesia dan berkedudukan di Indonesia; 2. Perempuan dari keluarga pra / cukup sejahtera yang sudah memiliki usaha atau akan usaha; 4 . Usia minimum 18 tahun dan maksimal 60 tahun; 5. Penduduk setempat, atau bertempat tinggal tetap (tidak kontrak/ kost); 6. Jika nasabah bertempat tinggal diatas tanah milik pihak
\end{abstract}


ketiga, maka Tim MMS harus mengisi Form Verifikasi Rumah di atas lahan milik orang lain; 7. Jika dalam 1 (satu) rumah terdapat beberapa keluarga, maka yang diperkenankan menjadi nasabah hanya 1 (satu) nasabah.

Kata Kunci - Prosedur Pembiayaan, Paket Masa Depan, Modal Usaha

\begin{abstract}
Islamic banks are financial institutions that function as fund collectors, distributors of funds and provide banking services to the public whose operational system is in accordance with Islamic law. The function of channeling funds to the public in the bank is the existence of financing. BTPN Syariah is one of the financial institutions that carries out the financing function through the Future Package Financing (PMD) product. The purpose of this study was to determine the Future Package Financing Procedure (PMD) at BTPN Syariah MMS Rengasdengklok, Karawang. The results of this study conclude that the Future Package is an integrated program of BTPN Syariah which is given to a group of women in rural areas who want to do business and have dreams of changing their lives, but do not have access to banking services. PMD prioritizes 4 (four) effective behaviors in achieving their dreams, namely BDKS (Dare to try, Discipline, Hard Work and Mutual Help). The requirements to become a PMD customer at BTPN Syariah bank are as follows: 1. Indonesian citizen and domiciled in Indonesia; 2 . Women from pre / moderately prosperous families who already have a business or will start a business; 4 . Minimum age is 18 years and maximum is 60 years; 5. Local resident, or permanent residence (not contract/boarding); 6 . If the customer resides on land owned by a third party, the MMS Team must fill out the Home Verification Form on land owned by another person; 7. If in 1 (one) house there are several families, then only 1 (one) customer is allowed to become a customer.
\end{abstract}

Keywords : Financing Procedure, Future Package, Business Capital.

\title{
I. PENDAHULUAN
}

Perkembangan dan persaingan antar Perbankan Syariah dalam memberikan layanan pembiayaan semakin beragam, salah satu contohnya adalah PT. Bank Tabungan Pensiunan Nasional (BTPN) Syariah, yang menghadirkan produk pembiayaan Paket Masa Depan (PMD) yaitu program pembiayaan terpadu dan produktif berdasarkan akad wakalah wal murabahah yang diperuntukkan bagi sekelompok wanita di pedesaan yang telah memiliki usaha atau untuk membangun suatu jenis usaha, tetapi tidak memiliki tambahan modal dan akses ke dunia perbankan. Program pembiayaan PMD ini lahir untuk membantu keluarga pra 
sejahtera dalam membangun dan mengelola usahanya, sehingga pembiayaan PMD hanya difokuskan untuk pembiayaan usaha produktif ${ }^{1}$.

Dimana dana yang disalurkan kepada setiap nasabah dapat digunakan untuk mengelola jenis usaha, sehingga dana tersebut dapat berkembang dan menghasilkan keuntungan baik bagi nasabah itu sendiri dalam menyelesaikan pembiayaan yang diajukan maupun bagi pihak bank dalam memperoleh kembali dana yang disalurkan serta bagi hasil dari pembiayaan tersebut. Di samping itu, BTPN Syariah secara rutin terus melakukan pendampingan dan pengawasan terhadap penggunaan dana yang diberikan kepada nasabah pembiayaan demi tercapainya program pemberdayaan PMD yang berkelanjutan dan terukur, sehingga pemberian pembiayaan tersebut sesuai sasaran².

Penelitian ini adalah untuk mengetahui Prosedur Pembiayaan Paket Masa Depan (PMD) Di BTPN Syariah MMS Rengasdengklok, Karawang. Penelitian ini juga hanya berfokus pada kelancaran pembayaran pembiayaan Paket Masa Depan untuk nasabah BTPN Syariah tidak berfokus pada perkembangan usaha nasabah. Penelitian-penelitian sebelumnya banyak mengkaji atau meneliti tentang pembiayaan Paket Masa Depan (PMD) yang berfokus pada kesejahteraan nasabah dan kelancaran pembiayaan nasabah tidak dengan pengaruh pembiayaan PMD bagi perkembangan usaha nasabah.

Penelitian ini mengkaji lebih dalam terkait Prosedur Pembiayaan Paket Masa Depan (PMD) terhadap Perkembangan Usaha Nasabah BTPN Syariah MMS Rengasdengklok, Karawang. Termasuk juga cara pengajuan pembiayaan untuk nasabah yang akan melakukan pinjaman untuk modal usaha nasabah di BTPN Syariah.

\section{A. Bank Syariah}

\section{TINJAUAN PUSTAKA}

Bank adalah suatu lembaga keuangan. Yaitu badan usaha yang berfungsi sebagai Financial Intermediary atau perantara keuangan dari dua pihak, yakni pihak yang berkelebihan dana dan pihak yang kekurangan dana (defisit). Berdasarkan undangundang perbankan No. 21 tahun 2008 tentang perbankan syariah. Dimana disebutkan bahwa: perbankan syariah adalah segala sesuatu yang menyangkut

${ }^{1}$ Ayu Lestari Wahyuni, “Analisis Pengaruh 5C Terhadap Kelancaran Pembayaran Pembiayaan Paket Masa Depan BTPNS (Studi Kasus Pada MMS Tambun Selatan)" (STIE Indonesia Banking School, 2019).

2 BTPN Syariah, "Tepat Pembiayaan Syariah - Kelompok," BTPN Syariah, 2010, https://www.btpnsyariah.com/web/guest/tepat-pembiayaan-syariah-kelompok.

JAMMIAH (Jurnal Ilmiah Mahasiswa Ekonomi Syariah), Volume 1, Nomor 2, September 2021 
tentang Bank Syariah dan Unit Usaha Syariah, mencakup kelembagaan, kegiatan usaha, serta cara dan proses melaksanakan kegiatan usahanya.

Bank syariah adalah bank yang beroperasi dengan tidak menagandalkan pada bunga. Bank Islam atau sering disebut dengan bank tanpa bunga, adalah lembaga keuangan/perbankan yang beroperasi dan produknya dikembangkan berdasarkan pada Al- Quran dan Hadist Nabi SAW ${ }^{3}$ Dengan demikian, bank syariah adalah lembaga keuangan atau perbankan yang usaha pokoknya memberikan pembiayaan dan jasa lainnya dalam lalu lintas pembayaran serta peredaran uang yang pengoperasiannya disesuaikan dengan prinsip-prinsip syariat Islam.

\section{B. Pengertian Pembiayaan Syariah}

Istilah pembiayaan berasal dari istilah biaya dasar, yang berarti uang yang dikeluarkan untuk mengatur, membangun dan melaksanakan suatu pekerjaan tertentu. Oleh karena itu, pembiayaan merupakan kegiatan yang mengeluarkan uang dalam rangka mendirikan, mendirikan, atau melakukan sesuatu. Dalam kamus lihai ekonomi Islam, pembiayaan diartikan sebagai penyediaan dana atau tagihan, dan bentuknya setara dengan:

1. Satu jenis. Transaksi bagi hasil dalam bentuk mudarabah dan musyarakah.

2. Transaksi sewa dalam bentuk ijarah atau sewa beli dalam bentuk ijarah mumtahiyah bittamlik.

3. Perdagangan dalam bentuk piutang dari Murabahah, Salam, istisna.

4. Transaksi pinjaman dalam bentuk piutang, dan

5. Transaksi sewa jasa dalam bentuk ljarah yang digunakan untuk transaksi multi layanan.

Menurut definisi di atas, pembiayaan berarti pihak yang memiliki dana terlalu banyak menyediakan / menyalurkan dana kepada pihak yang dana (peminjam) tidak mencukupi, maka peminjam harus mengembalikan dananya dalam jangka waktu tertentu dengan imbalan bagi hasil. Menurut Syafii Antonio, pembiayaan merupakan salah satu tanggung jawab utama bank, yaitu memberikan fasilitas untuk menyediakan dana guna memenuhi kebutuhan para pihak yang mengalami defisit.

\section{Jenis-Jenis Pembiayaan Bank Syariah ${ }^{4}$}

1. Menurut sifat penggunaannya

a. Pembiayaan produktif

${ }^{3}$ Muhammad, Manajemen Pembiayaan Bank Syariah (Yogyakarta: UUP AMP YKPN, 2015),5.

${ }^{4}$ Ikatan Bankir Indonesia. (2015). (1st and J Www.ikatanbankir.or.id, "Mengelola Bisnis Pembiayaan Bank Syariah (1st Ed.).," PT Gramedia Pustaka Utama, n.d.,/1www.ikatanbankir.or.id.

JAMMIAH (Jurnal Ilmiah Mahasiswa Ekonomi Syariah), Volume 1, Nomor 2, September 2021 
Pembiayaan yang ditujukan dalam memenuhi kebutuhan produksi dalam arti yang sangat luas. Pembiayaan produktif atau pembiayaan komersial, yaitu pembiayaan yang diberikan kepada perorangan atau badan usaha yang dipergunakan untuk membiayai suatu keghiatan yang produktif. Pembiayaan ini dapat berupa pembiayaan modal kerja, secara umum yang dimaksud dengan Pembiayaan Modal Kerja (PMK) adalah pembiayaan jangka pendek yang diberikan kepada perusahaan untuk membiayai kebutuhan modal kerja usahanya berdasarkan prinsip-prinsip syariah. Fasilita PMK dapat diberikan kepada seluruh sektor/subsektor ekonomi yang dinilai prospek, tidak bertentangan dengan syariah Islam dan tidak dilarang oleh ketentuan perundang-undangan yang berlaku.

b. Pembiayaan Konsumtif

Konsumtif, yaitu pembiayaan yang diberikan kepada nasabah yang dipergunakan untuk membiayai barang-barang konsumtif. Pembiayaan ini umumnya untuk perorangan seperti untuk pembelian rumah tinggal, pembelian mobil untuk keperluan pribadi, dan lainnya yang digunakan untuk kebutuhan pribadi. pembiayaan komersil untuk pemenuhan kebutuhan barang konsumsi.

2. Jenis Pembiayaan Berdasarkan Jangaka Waktu

a. Pembiayaan Janka Pendek, yaitu fasilitas pembiayaan dengan tenggang waktu pelunasan kepada bank tidak lebih dari 1 tahun.

b. Pembiayaan Jangka Menengah, yaitu fasilitas pembiayaan dengan tenggang waktu pelunasan kepada bank lebih dari 1 tahun -3 tahun.

c. Pembiayaan Jangka Panjang, yaitu fasilitas pembiayaan dengan jangka waktu pembiayaan yang diberikan lebih dari 3 tahun.

3. Jenis pembiayaan dilihat dari keperluan nasabah, yang dijelaskan sebagai berikut:

a. Pembiayaan Modal Kerja, pembiayaan yang digunakan intuk menambah modal kerja suatu perusahaan.

b. Pembiayaan Investasi, pembiayaan yang digunakan untuk pembelian barangbarang modal beserta jasa yang diperlukan

\section{Dasar Hukum Pembiayaan}

Dalam Al-qur'an, kata pembiayaan sendiri tidak secara ekplisit disebutkan, akan tetapi keberadaannya dijelaskan oleh ayat-ayat Al-qur'an dan contoh dari Rasulullah SAW serta tradisi para sahabat. Dasar hukum pembiayaan tersebut adalah sebagai berikut

1. Al-Quran

JAMMIAH (Jurnal Ilmiah Mahasiswa Ekonomi Syariah), Volume 1, Nomor 2, September 2021 http://journal.sties-purwakarta.ac.id/index.php/jammiah/ ISSN: 2797-040X (Media Online) 2797-197X (Media Cetak) 


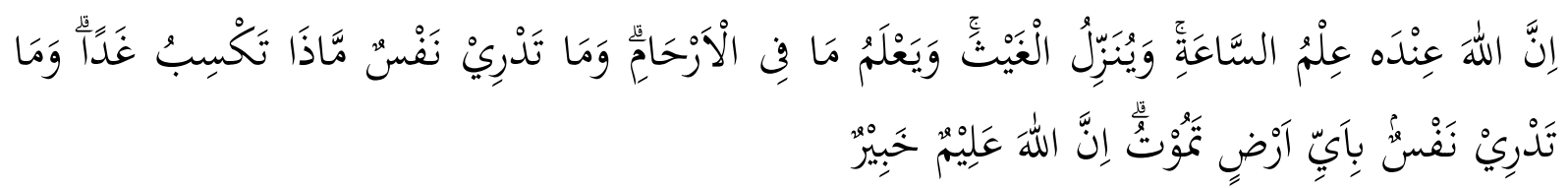

"Sesungguhnya hanya di sisi Allah ilmu tentang hari Kiamat; dan Dia yang menurunkan hujan, dan mengetahui apa yang ada dalam rahim. Dan tidak ada seorang pun yang dapat mengetahui (dengan pasti) apa yang akan dikerjakannya besok. Dan tidak ada seorang pun yang dapat mengetahui di bumi mana dia akan mati. Sungguh, Allah Maha Mengetahui, Maha Mengenal."

2. Al-Hadits

Dari riwayat Abu Dawud nomer 2895 mengatakan tentang Jual beli, dan makna dari orang yang makan riba dan orang yanng memberikannya, seperti yang dikatakannya berikut ini:

"Telah menceritakan kepada kami Ahmad bin Yunus, Telah menceritakan kepada kami Simak, telah menceritakan kepadaku Abdurahman bin Abdullah bin Mas'ud dari ayahnya, ia berkata; Rasulullah Shalallahu 'Alaihi Wasallam melaknat orang yang makan riba, orang yang memberi makan riba, saksinya dan penulisannya." (HR. Abu Dawud).

\section{E. Fungsi pembiayaan}

Ada beberapa fungsi dari pembiayaan yang diberikan oleh bank syariah kepada masyarakat penerima, diantaranya $:^{5}$

1. Meningkatkan daya guna uang

Dana yang mengendap di bank (dana pihak ketiga) tidaklah idle (diam) dan disalurkan untuk usaha-usaha yang bermanfaat, baik bagi pengusaha maupub masyarakat.

2. Meningkatkan daya guna barang

Produsen dengan bantuan pembiayaan bank dapat memprodusir bahan mentah menjadi bahan jadi sehingga utility bahan meningkat.

3. Menigkatkan peredaran uang

Pembiayaan yang disalurkan via rekening koran pengusaha meciptakan peredaran uang giral dan sebagaiya.

4. Menimbulkan kegairahan berusaha

Bantuan pembiayaan yag diterima pengusaha dari bank inilah kemudian yang digunakan untuk memperbesar volume usaha dan produktivitas, masyarakat tidak perlu khawatir kekurangan modal.

${ }^{5}$ Muhammad., Manajemen Dana Bank Syariah. (Yogyakarta: EKONISIA., 2005).

JAMMIAH (Jurnal Ilmiah Mahasiswa Ekonomi Syariah), Volume 1, Nomor 2, September 2021

http://journal.sties-purwakarta.ac.id/index.php/jammiah/

ISSN: 2797-040X (Media Online) 2797-197X (Media Cetak) 
5. Stabilitas ekonomi

Untuk menekan arus inflasi dan untuk usaha pembangunan ekonomi maka pembiayaan bank memegang peranan yang penting.

6. Sebagai jembatan untuk meni gkatkan pendapatan nasional

7. Sebagai alat hubungan ekonomi internasional.

\section{F. Perbandingan Penelitian Terdahulu}

Penelitian Prosedur Pembiayaan Paket Masa Depan (PMD) Di BTPN Syariah MMS Rengasdengklok, Karawang sudah banyak dilakukan oleh peneliti sebelumya seperti yang dilakukan oleh Ahmad Subhani. ${ }^{6}$ Hasil dari penelitian ini menunjukkan bahwa mekanisme produk pembiayaan paket masa depan Bank Tabungan Pensiunan Nasional melalui Mobile Marketing Syariah di Kabupaten Kotawaringin Timur sudah sesuai dengan Standar Operasional Prosedur (SOP) yang telah ditetapkan oleh Otoritas Jasa Keuangan dalam peraturannya Nomor 31/POJK.05/2014. Penelitian ini mengkaji lebih dalam terkait Prosedur Pembiayaan Paket Masa Depan (PMD) terhadap Perkembangan Usaha Nasabah BTPN Syariah MMS Rengasdengklok, Karawang. Termasuk juga cara pengajuan pembiayaan untuk nasabah yang akan melakukan pinjaman untuk modal usaha nasabah di BTPN Syariah.

Selanjutnya penelitian dilakukan oleh Dini Kusumaningrum. ${ }^{7}$ Hasil penelitian ini menjelaskan sektor perekonomian di Indonesia, Usaha Mikro Kecil Menengah (UMKM) menjadi salah satu penunjang sektor ekonomi yang penting karena keberadaannya yang sudah menjamur. Dalam UMKM keberadaan modal usaha menjadi faktor utama dalam perkembangan usaha tersebut. Dalam hal ini dunia perbankan berlomba-lomba mengeluarkan pembiayaan guna memenuhi kebutuhan penggiat UMKM tersebut. Tidak terkecuali Perbankan Syariah yang juga mengeluarkan pembiayaan dengan sistem tanggung renteng dengan akad kafalah dan tanpa jaminan. Pembiayaan dengan sistem tanggung renteng memang dikhususkan untuk memudahkan penggiat Usaha Mikro Kecil Menengah (UMKM) untuk memenuhi kebutuhan modal demi kemajuan usahanya. Fokus pada penelitian ini adalah untuk mengetahui pengaruh penerapan sistem tanggung renteng, pendampingan dan nisbah bagi hasil terhadap perkembangan usaha nasabah BTPN Syariah di Desa Sambongsari, Weleri, Kendal. Penelitian ini mengkaji lebih dalam terkait Prosedur Pembiayaan Paket Masa Depan (PMD) terhadap Perkembangan

${ }^{6}$ Ahad Subhani, “Dampak Produk Pembiayaan Paket Masa Depan Bank Tabungan Pensiunan Nasional Syariah Melalui Mobile Marketing Syariah Di Kabupaten Kotawaringin Timur" (IAIN Palangka Raya, 2019).

${ }^{7}$ Dini Kusumaningrum, "Pengaruh Pembiayaan Tanggung Renteng, Pendampingan Dan Nisbah Bagi Hasil Terhadap Perkembangan Usaha Mikro Nasabah : Studi Kasus Pada Nasabah Pembiayaan Usaha Mikro BTPN Syariah Desa Sambongsari Weleri Kabupaten Kendal." (UIN Walisongo, 2019).

JAMMIAH (Jurnal Ilmiah Mahasiswa Ekonomi Syariah), Volume 1, Nomor 2, September 2021 
Usaha Nasabah BTPN Syariah MMS Rengasdengklok, Karawang. Termasuk juga cara pengajuan pembiayaan untuk nasabah yang akan melakukan pinjaman untuk modal usaha nasabah di BTPN Syariah.

Selanjutnya penelitian yang dilakukan oleh Riris Tri Asmorowati. ${ }^{8}$ Hasil dari evaluasi dengan model CIPP didapat Program PMD BTPN telah didistribusikan sesuai sasaran dan tujuannya, pada pelaksanaan akad pembiayaan dengan menggunakan akad Wakalah wal Murabahah tidak menyalahi prinsip syariah dimana pelaksanaan akad dilakukan secara terpisah, tetapi program pembiayaan PMD belum memberikan dampak pemberdayaan yang maksimal kepada seluruh wanita miskin yang menjadi nasabah karena kurang maksimalnya kegiatan pendampingan yang diberikan oleh petugas. Penelitian ini mengkaji lebih dalam terkait Prosedur Pembiayaan Paket Masa Depan (PMD) terhadap Perkembangan Usaha Nasabah BTPN Syariah MMS Rengasdengklok, Karawang. Termasuk juga cara pengajuan pembiayaan untuk nasabah yang akan melakukan pinjaman untuk modal usaha nasabah di BTPN Syariah.

\section{HASIL DAN PEMBAHASAN}

\section{A. Prosedur Pembiayaan Paket Masa Depan (PMD) Di BTPN Syariah MMS Rengasdengklok, Karawang}

Islam merupakan agama yang paling sempurna yang mengatur semua aspek kehidupan berlandaskan pada Al-Qur'an dan Hadits. Salah satunya dalam kegiatan bermuamalah. Kegiatan pembiayaan merupakan salah satu bentuk contoh bermuamalah. Secara umum yang dimaksud dengan pembiayaan adalah pendanaan yang dilakukan oleh lembaga keuangan (perbankan syariah) kepada nasabah yang dapat digunakan untuk memenuhi kebutuhannya berdasarkan dengan prinsipprinsip syariah. Salah satu bentuk produk pembiayaan dalam perbankan syariah yaitu pembiayaan Paket Masa Depan (PMD). Dimana produk ini merupakan satusatunya produk pembiayaan yang ada pada BTPN Syariah.

Kegiatan umum BTPN Syariah sebagai Bank baru terus berupaya menyediakan produk-produk unggulan yang mengedepankan pemenuhan kebutuhan nasabah untuk memiliki kehidupan yang lebih baik. Fokus pada pemberdayaan nasabah pra sejahtera produktif. BTPN Syariah memiliki produk utama yaitu produk pembiayaan. Produk ini semata-mata ditujukan untuk memberdayakan keluarga pra-sejahtera

${ }^{8}$ Riris Tri Asmorowati, “"Evaluasi Program Paket Masa Depan (PMD) Dalam Pemberdayaan Ekonomi Masyarakat Perempuan Miskin Di Pedesaan (Studi Pada BTPN Syariah MMS Eromoko)," Islamic Economics, 2018.

JAMMIAH (Jurnal Ilmiah Mahasiswa Ekonomi Syariah), Volume 1, Nomor 2, September 2021 http://journal.sties-purwakarta.ac.id/index.php/jammiah/ ISSN: 2797-040X (Media Online) 2797-197X (Media Cetak) 
produktif. Pembiayaan Produk BTPN Syariah dalam hal pembiayaan adalah Produk Paket Masa Depan (PMD) ${ }^{9}$.

Paket Masa Depan adalah program terpadu BTPN Syariah yang diberikan kepada sekelompok perempuan di pedesaan yang ingin berusaha dan memiliki impian untuk merubah hidup, tetapi tidak memiliki akses ke layanan perbankan. PMD mengedepankan 4 (empat) prilaku efektif dalam menggapai mimpi mereka yaitu BDKS (Berani berusaha, Disiplin, Kerja Keras dan Saling Bantu). BTPN Syariah secara rutin melakukan program pemberdayaan yang berkelanjutan dan terukur ${ }^{10}$.

Berdasarkan hasil penelitian yang telah dilakukan pada variabel perkembangan usaha, diketahui bahwa pembiayaan Paket Masa Depan (PMD) memiliki nilai probabilitas yang menunjukan Hasil analisis menunjukkan pengaruh dari pembiayaan PMD untuk perkembangan usaha nasabah cukup besar dibanding faktor pemasaran dan tenaga kerja. Hasil penelitian ini didukung oleh bukti empiris dari penelitian terdahulu yang dilakukan oleh Lukytawati Anggraeni (2013). ${ }^{11}$ Dimana nasabah dapat membuka peluang untuk usaha melalui pembiayaan Paket Masa Depan (PMD), kebanyakan nasabah berawal dari usaha kecil-kecilan sampai ada yang berkembang berkat dari pembiayaan PMD yang nasabah ajukan . Positifnya semakin usaha nasabah berkembang, pembiayaan yang nasabah terima juga semakin besar, melihat dari hasil usahanya. Hal tersebut juga tidak terlepas dari syarat pengajuan nasabah yang tidak terlalu rumit, sehingga banyak yang melakukan pengajuan pembiayaan.

Persyaratan untuk menjadi nasabah PMD terdiri dari beberapa aspek, diantaranya aspek hukum, dengan diaturnya batasan usia seseorang yang dianggap sudah dewasa dan boleh melakukan perjanjian/akad, karena jika usia nasabah belum dewasa, maka akibatnya perjanjian/akad yang dibuat akan menjadi batal. Selain itu aspek kepatuhan terhadap ketentuan bank Indonesia, bahwa pembiayaan harus diberikan kepada WNI, dan tak kalah penting harus memastikan bahwa pembiayaan diberikan kepada target market yang ditentukan oleh Bank.

\section{Syarat Menjadi Nasabah PMD di BTPN Syariah}

Berikut syarat untuk menjadi nasabah PMD di bank BTPN Syariah, ${ }^{12}$ sebagai berikut :

${ }^{9}$ Hasil wawancara dengan Manager Sentra yaitu Ibu Tasmah Halimanah, pada hari Selasa tanggal 25 Agustus 2020 pukul 15.00 WIB

${ }^{10}$ Hasil wawancara dengan Pembina Sentra yaitu saudari Rindi, pada hari Rabu tanggal 26 Agustus 2020 pukul 16.00 WIB

11 Lukytawati Anggraeni, "Akses UMKM Terhadap Pembiayaan Mikro Syariah Dan Dampaknya Terhadap Perkembangan Usaha Kasus BMT Tadbiirul Ummah Kabupaten Bogor," Jurnal Al-Muzara'ah Vol. I No. (2013).

12 Panduan Paket Masa Depan...80, Edisi Revisi tahun 2012, (Jakarta : BTPN Syariah,2012)

JAMMIAH (Jurnal Ilmiah Mahasiswa Ekonomi Syariah), Volume 1, Nomor 2, September 2021 
a. Perorangan, Warga Negara Indonesia (WNI) dan berkedudukan di Indonesia.

b. Perempuan dari keluarga pra / cukup sejahtera yang sudah memiliki usaha atau yang ingin memiliki usaha.

c. Usia minimum 18 tahun bagi perempuan yang sudah/pernah menikah dan minimal 21 tahun bagi yang belum menikah dengan usia maksimal pada saat pengajuan 59 tahun dan pada saat pelunasa maksimal usia nya 60 tahun.

d. Penduduk setempat yang bertempat tinggal tetap diwilayah/kampung tersebut (tidak kontrak/ kost).

e. Apabila diketahui nasabah bertempat tinggal diatas tanah milik pihak ketiga, maka Tim MMS harus mengisi Form Verifikasi Rumah di atas lahan milik orang lain.

f. Jika dalam 1 (satu) rumah terdapat beberapa keluarga atau beberapa calon nasabah, maka yang diperkenankan menjadi nasabah hanya 1 (satu) diantaranya.

Tujuan pembiayaan ini adalah untuk modal usaha, baik usaha baru maupun penambahan usaha yang sudah berjalan sesuai dengan prinsip syariah. Dilarang memberikan pembiayaan di luar prinsip syariah seperti untuk usaha jual daging babi, menjual kupon judi, minuman keras, atau digunakan untuk membayar pinjaman di tempat lain.

\section{Prosedur Pemberian Pembiayaan PMD di BTPN Syariah}

Prosedur Pemberian Pembiayaan PMD Pemberian pembiayaan kepada nasabah diawali dengan menyeleksi nasabah yang dilakukan dengan cara sebagai berikut ${ }^{13}$ :

a. Melakukan Pre Marketing

Pada tahapan Pre marketing yang dilakukan oleh tim MMS terdapat tiga tingkatan pertemuan, yaitu sebagai berikut:

1) Silaturahmi Dengan Aparat (SDA) setempat

Tim MMS melakukan pertemuan dengan Aparat Desa, baik itu kelurahan maupun kecamatan. Untuk bersilahturahmi sekaligus mensosialisasi produk Paket Masa Depan yang akan diberikan kepada warga di sekitar desa tersebut. Selain bersilahturahmi dan menjelasan produk PMD, Tim MMS juga bisa mencari informasi kepada Aparat Desa mengenai calon nasabah yang akan dikasih pembiayaan nantinya.

2) Mini Meeting (MM)

Team MMS melakukan kunjungan langsung kepada para perempuan yang dijadikan target market, tujuan utama dari MM ini yaitu untuk melakukan

${ }^{13}$ Panduan Paket Masa Depan...84, Edisi Revisi tahun 2012, (Jakarta : BTPN Syariah,2012)

JAMMIAH (Jurnal Ilmiah Mahasiswa Ekonomi Syariah), Volume 1, Nomor 2, September 2021 
survey lokasi agar team MMS tau lokasi rumah nasabah selanjutnya untuk menggali kebutuhan dan mencari sumber motivasi untuk mewujudkan mimpi ibu-ibu serta memperkenalkan produk Paket Masa Depan secara singkat.

3) Projection Meeting (PM)

Ini merupakan tindak lanjut dari Mini Meeting kepada calon nasabah, untuk menggali kebutuhan calon nasabah, memberi motivasi dan menjelaskan secara detail tujuan, manfaat dan ketentuan mengenai Paket Masa Depan serta menumbuhkan motivasi kepada ibu-ibu agar Berani berusaha, Displin, Kerja keras dan Saling bantu.

b. Survey dan wawancara (SW)

Survey dilakukan untuk mengetahui lokasi usaha nasabah serta menganalisa omset usaha nasabah agar tim MMS bisa mempertimbangkan berapa pembiayaan yang akan diberikan untuk tahap awal. Selajutnya melakukan wawancara langsung kepada nasabah serta mencari informasi karakter nasabah kepada tetangganya.

c. Memberikan Pelatihan Dasar Keanggotaan (PDK) termasuk pembentukan group, pembentukan sentra dan penentuan lokasi sentra.

1) Pelatihan Calon nasabah yang sudah diseleksi dan dilakukan survey wawancara, selanjutnya akan diberikan Pelatihan Dasar Keanggotaan (PDK) yaitu memberikan informasi secara rinci mengenai produk Paket Masa Depan dan pelatihan mengenai pengelolaan keuangan secara sederhana. PDK wajib diikuti oleh semua calon nasabah dengan kehadiran 100\%. Pelatihan ini diberikan oleh Bank kepada nasabah secara gratis. Calon nasabah wajib lulus PDK sebagai salah satu syarat untuk dapat mengajukan pembiayaan, sebagai bukti kelulusan. Nasabah akan dilantik oleh MS/WMS dan Bank akan menerbitkan tanda kelulusan PDK yang dibuat dalam 2 (dua) lembar, yang mana 1 lembar yang asli disimpan oleh bank dan 1 lembar copian diberikan kepada ketua sentra pada waktu pelantikan untuk disimpan oleh ketua sentra. PDK dilakukan selama 5 (lima) hari berturutturut dengan materi yang berbeda-beda bagi nasabah yang baru bergabung dengan pembiayaan PMD, bagi nasabah yang sudah mendapatkan pembiayaan PMD pada tahap awal dan kemudian ingin melanjutkan ke tahap selanjutnya maka nasabah tersebut mendapatkan PDK selama 1 (satu) hari atau paling lama 3 (tiga) hari.

2) Pembentukan grup dan sentra

Pembentukan grup dan sentra dilakukan pada saat PDK, Yaitu : 
a) Grup Setiap grup terdiri dari minimal 1 orang dan maksimal 5 orang, termasuk 1 ketua grup yang dapat membaca dan menulis. Pemilihan ketua grup menjadi wewenang dari anggota grup. Penambahan anggota grup dapat dilakukan setiap saat, selama tidak melebihi jumlah anggota maksimal 1 grup. Ibu, anak atau saudara kandung tidak boleh satu group.

b) Sentra Setiap 1 sentra terdiri dari minimal 1 grup dan maksimal 5 grup yang dipimpin oleh ketua sentra yang bisa membaca dan menulis. Pemilihan ketua sentra sepenuhnya menjadi wewenang dari anggota sentra.

3) Penentuan rumah/lokasi sentra

Rumah sentra adalah tempat Pertemuan Rutin Sentra (PRS), bisa merupakan rumah salah satu nasabah, atau tempat lainnya yang disepakati sebagai tempat PRS seluruh anggota sentra.

4) Maintenance Nasabah

Maintenance Nasabah maksudnya adalah pendampingan terhadap nasabah. Pendampingan ini meliputi 3 (Tiga) hal yaitu ${ }^{14}$ :

a) Pertemuan Rutin Sentra (PRS) Pertemuan Rutin Sentra (PRS) dilakukan 1x dalam 2 (dua) minggu setelah pencairan pembiayaan PMD. Semua kegiatan harus dilakukan pada saat PRS seperti membayar angsuran, setor atau tarik tabungan dll. PRS dilakukan ditempat yang telah disepakati bersama pada saat Mini Meeting (MM). Pada saat PRS pihak bank akan selalu mengingatkan 4 (empat) prilaku yang harus dilakukan nasabah yaitu Berani berusaha, Disiplin, Kerja Keras dan saling bantu.

b) Monitoring Usaha (MU) dan Surprise Visit (SV)

Monitoring Usaha dilakukan untuk melihat apakah ada perubahan pada nasabah yang telah mendapatkan pembiayaan PMD. MU dilakukan selambat-lambatnya 1(satu) bulan setelah pencairan. Jika dalam MU didapati nasabah menggunakan pembiayaan tidak sesuai dengan tujuan awal maka pihak Bank akan memberikan peringatan dan bisa nasabah tersebut tidak mendapatkan Top Up atau pembiayaan siklus selanjutnya.

c) Surprise Visit (SV)

SV dilakukan secara Sampling minimal 4(empat) orang nasabah dan dilaksanakan maksimal 3 bulan sejak pembiayaan dicairkan. Mitigasi Resiko Pembiayaan Bermasalah Pembiayaan bermasalah adalah suatu penyaluran dana yang dilakukan oleh lembaga pembiayaan dalam hal

${ }_{14}$ Panduan Paket Masa Depan...124, Edisi Revisi tahun 2012, (Jakarta : BTPN Syariah,2012) 
ini Bank Syariah kepada nasabah, yang dalam pelaksanaan pembayaran pembiayaan oleh nasabah itu terjadi hal-hal seperti pengembalian angsuran yang tidak lancar, tidak menepati jadwal angsuran, pembiayaan yang debiturnya tidak memenuhi persyaratan yang dijanjikan, Sehingga hal-hal tersebut memberikan dampak negative bagi kedua belah pihak (debitur dan kreditur.

\section{KESIMPULAN}

Paket Masa Depan adalah program terpadu BTPN Syariah yang diberikan kepada sekelompok perempuan di pedesaan yang ingin berusaha dan memiliki impian untuk merubah hidup, tetapi tidak memiliki akses ke layanan perbankan. PMD mengedepankan 4 (empat) prilaku efektif dalam menggapai mimpi mereka yaitu BDKS (Berani berusaha, Disiplin, Kerja Keras dan Saling Bantu). Berikut syarat untuk menjadi nasabah PMD di bank BTPN Syariah, sebagai berikut :

1. Perorangan, Warga Negara Indonesia (WNI) dan berkedudukan di Indonesia.

2. Perempuan dari keluarga pra / cukup sejahtera yang sudah memiliki usaha

3. atau yang ingin memiliki usaha.

4. Usia minimum 18 tahun bagi perempuan yang sudah/pernah menikah dan minimal 21 tahun bagi yang belum menikah dengan usia maksimal pada saat pengajuan 59 tahun dan pada saat pelunasa maksimal usia nya 60 tahun.

5. Penduduk setempat yang bertempat tinggal tetap diwilayah/kampung tersebut (tidak kontrak/ kost).

6. Apabila diketahui nasabah bertempat tinggal diatas tanah milik pihak ketiga, maka Tim MMS harus mengisi Form Verifikasi Rumah di atas lahan milik orang lain.

7. Jika dalam 1 (satu) rumah terdapat beberapa keluarga atau beberapa calon nasabah, maka yang diperkenankan menjadi nasabah hanya 1 (satu) diantaranya.

\section{DAFTAR PUSTAKA}

(1st, Ikatan Bankir Indonesia. (2015)., and J Www.ikatanbankir.or.id. "Mengelola Bisnia Pembiayaan Bank Syariah (1st Ed.)." PT Gramedia Pustaka Utama, n.d.

Asmorowati, Riris Tri. “"Evaluasi Program Paket Masa Depan (PMD) Dalam Pemberdayaan Ekonomi Masyarakat Perempuan Miskin Di Pedesaan (Studi Pada BTPN Syariah MMS Eromoko)." Islamic Economics, 2018.

BTPN Syariah. “Tepat Pembiayaan Syariah - Kelompok.” BTPN Syariah, 2010. https://www.btpnsyariah.com/web/guest/tepat-pembiayaan-syariah-kelompok.

JAMMIAH (Jurnal Ilmiah Mahasiswa Ekonomi Syariah), Volume 1, Nomor 2, September 2021 http://journal.sties-purwakarta.ac.id/index.php/jammiah/ ISSN: 2797-040X (Media Online) 2797-197X (Media Cetak) 
Kusumaningrum, Dini. "Pengaruh Pembiayaan Tanggung Renteng, Pendampingan Dan Nisbah Bagi Hasil Terhadap Perkembangan Usaha Mikro Nasabah : Studi Kasus Pada Nasabah Pembiayaan Usaha Mikro BTPN Syariah Desa Sambongsari Weleri Kabupaten Kendal." UIN Walisongo, 2019.

Lukytawati Anggraeni. “Akses UMKM Terhadap Pembiayaan Mikro Syariah Dan Dampaknya Terhadap Perkembangan Usaha Kasus BMT Tadbiirul Ummah Kabupaten Bogor,." Jurnal Al-Muzara'ah Vol. I No. (2013).

Muhammad. Manajemen Dana Bank Syariah. Yogyakarta: EKONISIA., 2005.

Muhammad. Manajemen Pembiayaan Bank Syariah. Yogyakarta: UUP AMP YKPN, 2015. Subhani, Ahmad. “Dampak Produk Pembiayaan Paket Masa Depan Bank Tabungan Pensiunan Nasional Syariah Melalui Mobile Marketing Syariah Di Kabupaten Kotawaringin Timur." IAIN Palangka Raya, 2019.

Wahyuni, Ayu Lestari. “Analisis Pengaruh 5C Terhadap Kelancaran Pembayaran Pembiayaan Paket Masa Depan BTPNS (Studi Kasus Pada MMS Tambun Selatan)." STIE Indonesia Banking School, 2019. 